\title{
Multiple Kagu Rhynochetos jubatus deaths caused by dog attacks at a high-altitude study site on Pic Ningua, New Caledonia
}

\author{
GAVIN R. HUNT, ROD HAY and CLARE J. VELTMAN
}

\section{Summary}

Dog predation has been cited as an important factor in the decline of the threatened Kagu of New Caledonia but direct evidence of predation was restricted to single kills. Here we report the first documented case of multiple Kagu deaths caused by dogs, which occurred at our 200 ha, high-altitude $(800-1,300 \mathrm{~m})$ study site on Pic Ningua. The deaths were discovered because we were radio-tracking Kagus there as part of our behavioural study on the birds. In 1993 we found 20 Kagus either dead (15) or wounded (5; one survived) from dog attacks in four distinct episodes over a 14-week period from late April to early August. Two other birds whose older remains were found also probably died from dog attacks. Of the 22 birds 18 wore radio transmitters; the four non-radio-tracked birds were found by chance. Dogs errant from a nearby tribal village were strongly implicated in carrying out most, if not all, of the attacks. They climbed around 1,000 $\mathrm{m}$ in altitude to reach the study site and attacked birds there on repeat visits to the site. The apparent recent disappearance of Kagus in forest neighbouring the study site suggests the dogs caused the deaths of most of the birds on the peak. Dog predation is probably an ongoing problem for the Kagu and the attacks at Pic Ningua are probably not an isolated incident. Protecting birds outside Rivière Bleue Park from dogs will require: (1) establishment of additional intensively managed reserves; (2) continuing education of the public and administrators about the need for Kagu protection and associated dog control; (3) involvement of tribal communities in Kagu conservation; and (4) enforcement of dog control laws. The events at Pic Ningua demonstrate the necessity for additional and non-connected reserves to safeguard against catastrophes and increase the probability of long-term Kagu persistence in the wild.

\section{Introduction}

The endemic Kagu Rhynochetos jubatus of New Caledonia is a flightless, ground-nesting forest bird averaging $c .900 \mathrm{~g}$ in weight. Very little sexual size dimorphism exists in the species (Brégulla 1987). Birds are diurnal and forage much of the day for soil and litter fauna. At low altitude, they roost mainly on low branches (c. $1.5 \mathrm{~m}$ above the ground) year round (Létocart 1991), but at high altitude in colder winter months they frequently roost in sheltered sites on the ground (G.R.H. unpubl. data). The birds form long-term pair bonds and hold large ( $c .20 \mathrm{ha}$ ) permanent territories where nesting (a one-egg clutch) usually occurs once, and very rarely twice, a year (Létocart 1991). Plumage colouration of adult Kagus is ash-grey and white making birds quite easily seen in sombre forest conditions. 


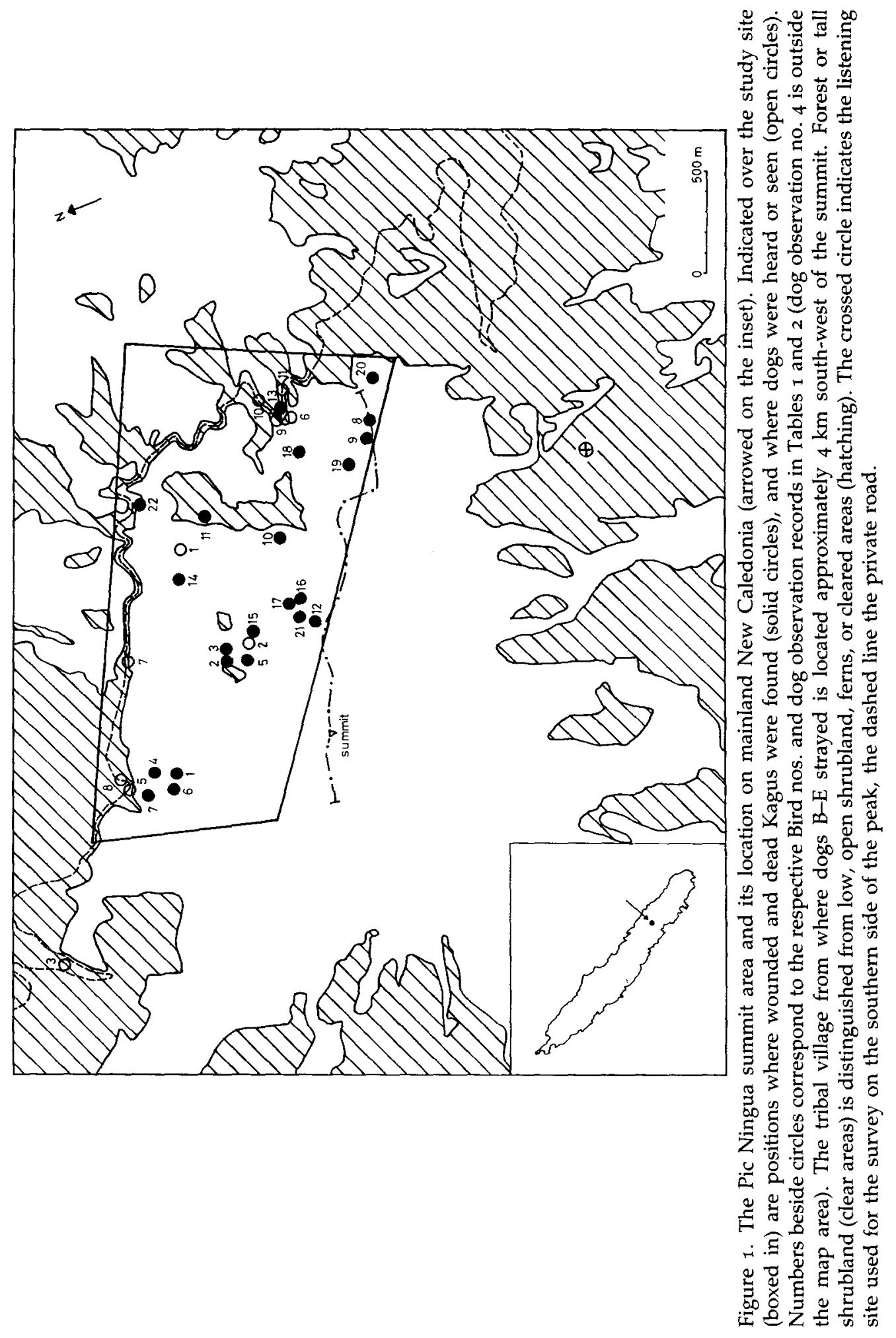


The Kagu evolved in the absence of mammalian predators. When threatened, or to protect chicks, adults open their wings to display their black and white banded primary feathers. In nest or chick defence they may also flap their wings on the ground in a typical distraction display feigning injury. Kagus are agile and can easily escape a human pursuer in forest habitat but are easy prey for dogs.

The Kagu is only present on the New Caledonian mainland, where it is a threatened species (Collar et al. 1994). After a preliminary survey by Thiollay (1989), its status was further clarified in 1991 by the first comprehensive field census in unprotected areas (Hunt 1996a) when 491 birds (177 pairs) were counted. Kagu distribution was fragmented with birds mostly restricted to remoter intact habitat at higher altitudes. Another 163 birds (63 pairs) were known at that time in the only protected Kagu area, Rivière Bleue Park (Létocart 1992).

Because of the Kagus' taxonomic distinctiveness (the only member of a monotypic family), its vulnerable lifestyle and its current status, local and international efforts have been made to try and ensure its long-term persistence in the wild (e.g. Thiollay 1989, Létocart 1992, Hunt 1996a, this study). Dog predation has been suggested as an important factor causing Kagu decline within its habitat (Sarasin 1913, Jeggo 1978, Seitre and Seitre 1990) but most evidence was anecdotal or circumstantial. Predation cases came from single kills by stray dogs (e.g. Létocart 1992), or reports by hunters whose dogs killed birds when hunting pigs or deer (e.g. M. Bull verbally 1993). Here we report the first documented case of multiple Kagu deaths caused by dogs, which occurred at our high-altitude study site on Pic Ningua in 1993. This confirms that dogs are dangerous predators of adult Kagus, and we discuss the implications for Kagu conservation.

\section{Methods}

Study site

Pic Ningua $(1,351 \mathrm{~m})$ is an ultrabasic peak centred between the south-west and north-east coasts of the mainland $\left(21^{\circ} 45^{\prime} \mathrm{S}, 166^{\circ} 8^{\prime} \mathrm{E}\right.$ ) (Figure 1 ). It is a relatively insular cone-shaped peak with slopes mostly descending to river valleys well below the summit. Forest (c. 60o ha) occurs mainly above $950 \mathrm{~m}$. A summit ridge divides the peak into two main areas, the northern and southern slopes, with forest of comparable size in each area. The study site covers approximately 200 ha primarily on the northern slopes, ranging from 800 to $1,300 \mathrm{~m}$ (Figure 1). The terrain here tends to be less steep and rocky than on other parts of the peak. Vegetation over the site varies from shrubland to montane forest, with some fern and cleared areas. A private road runs mostly below the study site at $950-1,100 \mathrm{~m}$. Slopes are steeper below the road where forest is often restricted to creek gullies. The road provides access to current nickel mining operations near Pic Ningua, and also for pig hunters who regularly hunt in the area on weekends. Pig hunting in the forest on Pic Ningua was halted from January 1993 when our Kagu research started there. 
Many kilometres of walking tracks were marked throughout the study site with red and white plastic tape tied to trees.

\section{Kagus at the study site}

Kagus were captured at the study site from late January 1993 and fitted with small two-stage radio transmitters positioned on their backs with cords looped around each wing. The same type of transmitter and attachment method had been used successfully for many years in Rivière Bleue Park (Létocart 1991). The wearing of radio transmitters causes no apparent restriction in the birds' movements. All birds caught also had two coloured plastic bands placed around each leg. Not all birds at the study site wore transmitters or were banded.

Twenty-two Kagus were banded at the study site at the time we discovered the first attacked bird in late April 1993. Fifteen of these birds wore radio transmitters. A banded bird and six new birds were fitted with radio transmitters at the study site over the period that we recorded the attacks. The 28 birds consisted of ten probable pairs, three adults (two of unknown status, and one roosted with a widowed bird), two unpaired adults or subadults with their parents, and three juveniles from the 1992 breeding season. The home ranges of pairs covered much of the study site, suggesting most Kagus there were known.

Our research programme involved locating both the roost site and foraging position of a radio-tracked bird in a 24 -h period each fortnight. Any additional locations were also recorded. Foraging positions were usually recorded between 11 hoo and 14hoo, when birds were not observed but only approached to within approximately 50-100 $\mathrm{m}$ (estimated from signal strength) to avoid disturbing them. Because birds were unseen and the likelihood of signal distortion due to the valley and ridge topography existed, foraging locations were not exact.

We mapped the home ranges of pairs which were radio-tracked before the attacks took place to compare the positions where attacked birds were first found with the areas they used prior to being attacked. We used the convex polygon method to establish home range boundaries around the plotted positions of roost sites and foraging locations of pairs. Data for the male and female of a pair were combined. The convex polygon method probably overestimates actual home range sizes of flightless forest birds when sample sizes are sufficiently large, and underestimates them when sample sizes are small (McLennan et al. 1987). Sample sizes here were small.

\section{Results}

In 1993, 20 Kagus were found dead $(n=15)$ or wounded $(n=5)$ at the study site in four distinct attack episodes: three episodes between late April and late May, and one in early August (Table 1). Four of the wounded birds subsequently died and the fifth one completely recovered after treatment with antibiotics. The remains of two other birds (nos. 21 and 22) were also found. Of the 22 birds 18 wore radio transmitters, and the four non-radio-tracked birds (nos. 9, 13, 21 and 22) were found by chance. The remains of the birds found dead $(n=17)$ consisted of feathers only $(n=5)$, feathers and one or more separate body parts $(n=6)$, partly eaten carcasses $(n=4$; birds, 3, 9, 18 and 
Table 1. Details of the 22 dead $(n=17)$ or wounded $(n=5)$ birds found after four dog attack episodes at Pic Ningua

\begin{tabular}{|c|c|c|c|c|c|c|}
\hline Bird & $\begin{array}{l}\text { Bird } \\
\text { status }\end{array}$ & Sex & $\begin{array}{l}\text { Date last } \\
\text { thought } \\
\text { unharmed }\end{array}$ & $\begin{array}{l}\text { Date } \\
\text { found } \\
\text { attacked }\end{array}$ & $\begin{array}{l}\text { Brief description of attacked birds } \\
\text { when found }\end{array}$ & $\begin{array}{l}\text { Transmitter/ } \\
\text { bands }\end{array}$ \\
\hline \multicolumn{7}{|c|}{ First attack episode } \\
\hline 1 & $2-A$ & $F$ & $12 / 4$ & $26 / 4$ & $\begin{array}{l}\text { Dead (feathers, head, foot, } \\
\text { digestive tract) }\end{array}$ & $\mathrm{T} / \mathrm{B}$ \\
\hline 2 & $3-\mathrm{A}$ & M & $14 / 4$ & $27 / 4$ & Dead (feathers, one wing) & $\mathrm{T} / \mathrm{B}$ \\
\hline 3 & $4^{-\mathrm{A}}$ & M & $20 / 4$ & $27 / 4$ & $\begin{array}{l}\text { Dead (wings, head, and legs on } \\
\text { carcass) }\end{array}$ & $\mathrm{T} / \mathrm{B}$ \\
\hline 4 & $1-\mathrm{A}$ & ? & $19 / 4$ & $27 / 4$ & Dead (feathers, section of leg) & $\mathrm{T} / \mathrm{B}$ \\
\hline 5 & $4-\mathrm{A}$ & $\mathrm{F}$ & $20 / 4$ & $28 / 4$ & Wounded, later died & $\mathrm{T} / \mathrm{B}$ \\
\hline 6 & 1-A & ? & $19 / 4$ & $28 / 4$ & Dead (feathers) & $\mathrm{T} / \mathrm{B}$ \\
\hline 7 & $2-A$ & $\mathrm{M}$ & $29 / 4$ & $2 / 5$ & Wounded, later died & $\mathrm{T} / \mathrm{B}$ \\
\hline \multicolumn{7}{|c|}{ Second attack episode } \\
\hline 8 & $7-\mathrm{A}$ & $?$ & $5^{\prime} 5$ & $9 / 5$ & Dead (feathers) & $\mathrm{T} / \mathrm{B}$ \\
\hline 9 & ?-A & $?$ & - & $9 / 5$ & $\begin{array}{l}\text { Dead (wings, one leg, and head } \\
\text { on carcass) }\end{array}$ & - \\
\hline 10 & 7-A & $?$ & $5 / 5$ & $9 / 5$ & Dead (feathers) & $\mathrm{T} / \mathrm{B}$ \\
\hline 11 & $?-\mathrm{J}$ & ? & $5 / 5$ & $9 / 5$ & Dead (feathers, digestive tract) & $\mathrm{T} / \mathrm{B}$ \\
\hline \multicolumn{7}{|c|}{ Third attack episode } \\
\hline 12 & 8-A & M & $20 / 5$ & $21 / 5$ & Dead (intact) & $T / B$ \\
\hline 13 & ?-A & ? & - & $23 / 5$ & Dead (intact) & - \\
\hline \multicolumn{7}{|c|}{ Fourth attack episode } \\
\hline 14 & $5-\mathrm{A}$ & M & $1 / 8$ & $5 / 8$ & Dead (feathers, head, one foot) & $\mathrm{T} / \mathrm{B}$ \\
\hline 15 & $5-\mathrm{A}$ & $\mathrm{F}$ & $1 / 8$ & $5 / 8$ & Wounded, later recovered & $\mathrm{T} / \mathrm{B}$ \\
\hline 16 & $8-\mathrm{A}$ & M & $29 / 7$ & $5 / 8$ & $\begin{array}{l}\text { Wounded, later died (possible } \\
\text { new mate of bird } 8 \text { ) }\end{array}$ & $\mathrm{T} / \mathrm{B}$ \\
\hline 17 & 8-A & $\mathrm{F}$ & $29 / 7$ & $5 / 8$ & Wounded, later died & $\mathrm{T} / \mathrm{B}$ \\
\hline 18 & 9-A & ? & $4 / 8$ & $8 / 8$ & Dead (virtually intact) & $\mathrm{T} / \mathrm{B}$ \\
\hline 19 & 9-A & $?$ & $4 / 8$ & $8 / 8$ & Dead (feathers) & $\mathrm{T} / \mathrm{B}$ \\
\hline 20 & ?-J & $\mathrm{F}$ & $8 / 8$ & $10 / 8$ & Dead (virtually intact) & $\mathrm{T} / \mathrm{B}$ \\
\hline \multicolumn{7}{|c|}{ Approximate date of death unknown } \\
\hline 21 & ?-A & ? & - & $21 / 5$ & Dead (old feathers) & $\mathrm{B}$ ? \\
\hline 22 & $?-?$ & ? & _ & $12 / 10$ & Dead (old head, feathers) & $\mathrm{B}$ ? \\
\hline
\end{tabular}

Column 1, Kagu identification number; column 2, a bird's status is indicated by its family no. (families $1-5$ and $7-9, ?=$ family unknown) followed by its age $(\mathrm{A}=$ adult, $\mathrm{J}=$ juvenile, ? = unknown); column 3, sex of bird ( $\mathrm{F}=$ female, $\mathrm{M}=$ male, ?= unknown); column 6 indicates whether attacked birds were found wounded or dead (remains are briefly described); column $7, \mathrm{~T} /$ $B=$ fitted with a transmitter and leg bands, B? = may have been banded. Birds 7 and 20 may have been wounded before the date they were last thought unharmed. The remains of Birds 21 and 22 were found several weeks or months after they died.

20), and dead but uneaten carcasses $(n=2)$. Two of the partly eaten birds could have been scavenged by rats as only a small area of the breast of each bird was eaten and no bones were damaged. The sex of a bird did not appear to affect the risk of it being attacked.

The dead or wounded birds were found over a large area (Figure 1), including the southern side of the peak, although this bird may have been wounded on the northern side where it was first captured. Seven radio-tracked individuals which had partners (nos. 3, 4, 6, 8, 10, 12 and 15) were found outside the home ranges they were known to use before they or their partners were attacked (Figures 1 and 2). 


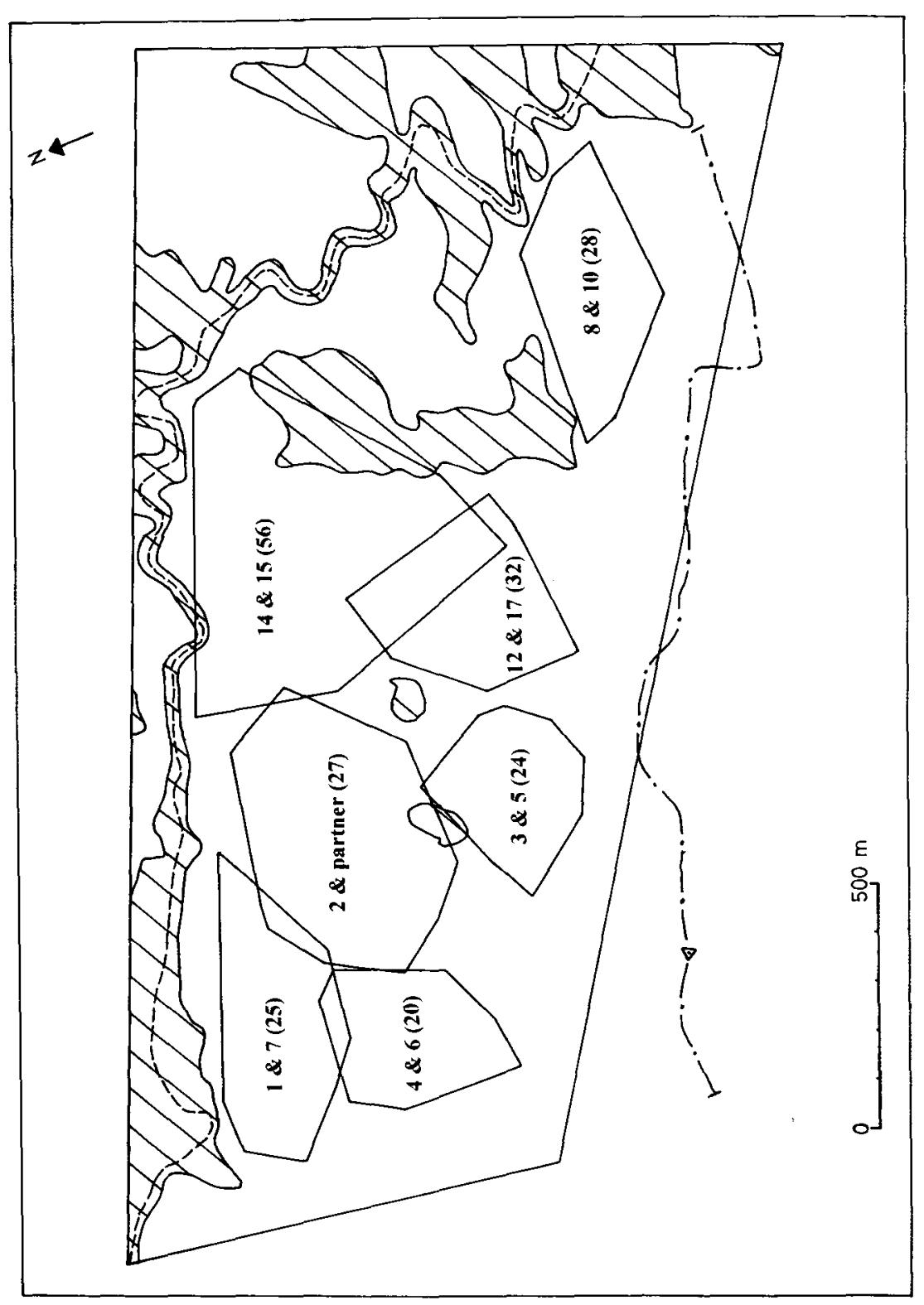

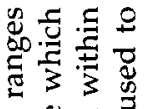

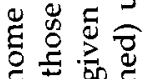
I 50

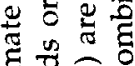
면

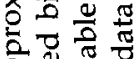
ते.

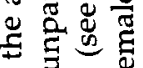

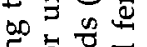

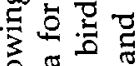

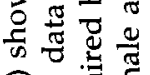
क范

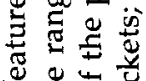
巳ั 홍 廿田

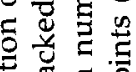
푱 중

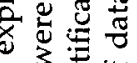
도웡

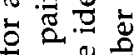

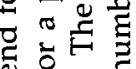
\& $\frac{0}{2} \frac{1}{2}$ $\rightarrow \overrightarrow{0}+\frac{2}{00}$

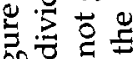

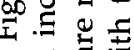
和薄 嗼 50 ఏ

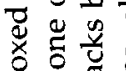
80 要 苋造焉 守的 蛋. 老芯 ฐ. है

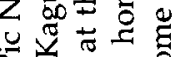
₹ 5 空

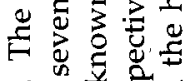
งे

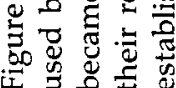


Table 2. Dog observation records (barking or visual sighting) at the study site on Pic Ningua between January 1993 and March 1995

\begin{tabular}{lllll}
\hline $\begin{array}{l}\text { Observation } \\
\text { number }\end{array}$ & $\begin{array}{l}\text { Type of } \\
\text { observation }\end{array}$ & Date & $\begin{array}{l}\text { Number } \\
\text { of dogs }\end{array}$ & $\begin{array}{l}\text { Dog identification } \\
\text { code }\end{array}$ \\
\hline 1 & Barking & $12 / 3 / 93$ & One & $?$ \\
2 & Barking & $20 / 4 / 93$ & One & $?$ \\
3 & Sighting & $25 / 4 / 93$ & One & A \\
4 & Sighting & $27 / 4 / 93$ & One & A \\
5 & Sighting & $4 / 5 / 93$ & Three & B, C, D \\
6 & Sighting & $7 / 5 / 93$ & One & B \\
7 & Sighting & $20 / 5 / 93$ & One & C \\
8 & Sighting & $20 / 5 / 93$ & Two & D, E (killed) \\
9 & Sighting & $22 / 5 / 93$ & Three & B, C, D \\
10 & Sighting & $22 / 5 / 93$ & Two & B, C \\
11 & Sighting & $24 / 5 / 93$ & One & B (killed) \\
\hline
\end{tabular}

Observations 3-6 were made by mine staff.

All transmitters on attacked birds were undamaged and working but some of the attachment cords were bitten through on eaten carcasses. Several leg bands on eaten carcasses contained single tooth marks presumably from pig or dog bites.

After the August attack episode, only five birds (four females and one male, all fitted with transmitters) were known at the study site. At 31 March 1995, only two new adult birds were known there. These were captured on 27 November 1993 and 12 April 1994 and also fitted with radio transmitters. As both birds spent time in the river valley below the road after being fitted with transmitters, they could have migrated to the study site from this area.

\section{Evidence for dog predation}

Eleven dog observations (barking or visual sighting) were recorded at the study site between late January 1993 and 31 March 1995 (Table 2, Figure 1). G.R.H. was present at the study site over this period for, on average, four days each week and dog observations by staff at the mine may have gone unrecorded. Dog scats were found on only two occasions between late January 1993 and March 1995: several recent scats on open ground at one location near the road during the period of the dog attacks and one fresh scat on 3 October 1993 on an old mining track near the other scats. Kagu remains were in all the scats. Five different dogs were identified at the study site: a lost hunting dog (white colouration, $\operatorname{dog} \mathrm{A}$ in Table 2) which mine staff identified and observed descending from Pic Ningua the day before the first attacked bird was found, and four dogs (B, C, D and E in Table 2) which belonged to a hunter from the tribal village in the valley on the southern side of the peak (see Figure 1 legend). Descriptions by mine staff of dogs they observed at the study site just before the second attack episode indicated dogs B, C and D and G.R.H. observed the same dogs two weeks later at the time of the third attack episode.

Wounds on Kagus consistent with dogs bites were circular puncture marks in the skin on and around the back region of all wounded and (intact) dead birds. No injuries were noticed around the head regions of attacked birds. We 
have no evidence that dogs buried Kagu remains or whole carcasses, as a stray dog did with a New Zealand Brown Kiwi Apteryx australis mantelli it killed (Taborsky 1988). A dog-related death for bird 22 seems likely as only the head was present. The feather remains of bird 21 appeared less than a few months old and its death may also have been caused by dogs.

A dog or dogs clearly caused the death of bird 13 which was found on 23 May in vegetation a few metres from the road. Obvious signs of a chase and capture by a dog were indicated by dog and Kagu footprints and Kagu feathers on the road next to where the bird was located. G.R.H. saw three dogs at the same site the previous evening (Table 2, Figure 1). Dog footprints (identified by $\mathrm{M}$. Bull) were only observed near one other dead Kagu, the feather remains of bird 8 found approximately $350 \mathrm{~m}$ from the road. The footprints were on a muddy track where they were easy to detect.

G.R.H. killed two dogs on the road at the study site, on 20 and 24 May 1993 (Table 2, Figure 1). Kagu remains were in the (full) stomach of one dog but as maggots were also present it had apparently recently eaten a Kagu carcass.

It seems improbable that pigs, which move relatively noisily through forest, could capture healthy adult Kagus. However, they did feed on Kagu carcasses as pig scats containing Kagu remains were found at the study site after the first Kagus were attacked in late April. No fresh pig scats containing Kagu remains were found after early May.

Feral cats Felis catus hunted in forest at the study site but the wounds on Kagus were not characteristic of cat attacks. No head and neck injuries were observed on birds but these were on a newly released captive-bred juvenile killed by a cat in Rivière Bleue Park (Y. Létocart verbally 1994). Also, no Kagu remains were ever found in cat scats G.R.H. inspected at the study site.

\section{Census of Kagus outside the study site}

In 1992, local hunters heard many Kagus sing in forest on the southern slopes of Pic Ningua. To check if researcher presence or activities at the study site had led to the dog attacks, part of the southern side (outside the study site) was surveyed for Kagus. The forest there was closer to the tribal village from where dogs B-E had strayed. The presence of many Kagus on the southern side would strongly suggest research activities on the northern side increased the risk of birds being attacked.

G.R.H. listened for early morning Kagu song (45 minutes before and after sunrise and the main period when birds sing; Jeggo 1978) from where the hunters had heard Kagus sing (Figure 1). On 21 mornings between 17 October 1993 and I February 1994 only one Kagu pair sang (on 30 December). At Mt Cindoa, a peak $7.5 \mathrm{~km}$ from Pic Ningua and where at least eight Kagu pairs lived, birds sang on each morning $(n=12)$ G.R.H. spent there over the same period. This suggests that nearly all the Kagus on Pic Ningua were attacked and not just those at the study site.

\section{Discussion}

There seems little doubt that dogs caused the deaths of at least 19 of the 21 Kagus known to have died at Pic Ningua. The numbers killed are almost 
certainly higher as Kagus without transmitters had also been on the peak. That four dead birds not fitted with transmitters were found by chance suggests this was the case.

Lost hunting $\operatorname{dog} A$ seen at the end of April could have been responsible for the first attack episode. The four dogs from the tribal village certainly appear responsible for the second and third attack episodes as they were seen around those times. No dogs were seen or heard at the study site around the August attack episode, suggesting that the $\operatorname{dog}(\mathrm{s})$ responsible reached the site without using the access road and thus also probably came from the tribal village.

It is a disturbing coincidence that dogs attacked Kagus at the study site soon (three months) after intensive research work started there. Kagus there were at high densities before the attacks, indicating that their numbers had been relatively stable for some years. Kagus fitted with transmitters and leg bands should not have been more at risk as birds without them were also attacked. The virtual disappearance of Kagus on the southern slopes suggests that dogs attacked birds there as well, therefore the research activities are unlikely to have attracted dogs to the peak. Dogs may have started attacking Kagus on the southern slopes then moved to the study site in search of more prey. No evidence suggests our marked walking tracks in the forest were used by dogs.

Seven attacked birds were found outside their previously known home ranges, suggesting that this phenomenon was predation-related. Dogs may have chased and/or carried the birds to the sites where they were found, or birds moved to the sites themselves after being left wounded. The remains of bird 3 included the head, indicating the bird was chased and/or carried to the site by a dog as pig-scavenged carcasses probably consisted of little else other than feathers. Although adult Kagus are easy prey for dogs, the circumstances surrounding the death of bird 13 suggest that they defend themselves by running to try and escape these predators.

The hunting behaviour of the dogs at Pic Ningua indicates that dogs are a serious threat to Kagus. In two of the four attack episodes wounded birds were left alive to die later and this may have also happened to many of the birds found dead. Thus the dogs caused the deaths of many more birds than was necessary for food.

Two behavioural aspects of the stray dogs from the tribal village are important: they probably hunted in a pack which should facilitate the finding and capture of birds, and they made repeat visits to forest with relatively difficult hunting access. Although the map distance from the village to the study site was not large $(4 \mathrm{~km})$, the dogs ascended from $200 \mathrm{~m}$ to probably around $1,300 \mathrm{~m}$ (bird 12 was found dead at $1,280 \mathrm{~m}$ ). They climbed over $1,000 \mathrm{~m}$ in altitude, demonstrating that Kagus at higher altitudes (where many unprotected birds now remain) are also at risk from predation by stray dogs. The lost hunting dog may have killed birds but it left the peak and apparently did not return. In contrast, the stray dogs made repeat visits to the study site to hunt, evidenced by sightings of the same individuals at the second and third attack episodes but not in between these times. Thus several dogs almost exterminated Kagus from the mountain top forest on Pic Ningua.

The dog attacks at Pic Ningua may not be an isolated event. Dog-related deaths of non-radio-tracked Kagus should be difficult to detect because they 
would occur in forest where any remains would be quickly removed by pigs. The situation seen with the similar-sized Brown Kiwi, also a flightless forest bird, may not be unlike that of the Kagu. There has been growing evidence after the first reported dog-caused multiple (radio-tracked) Brown Kiwi deaths (Taborsky 1988) that such incidents are a continuing problem and dog predation could be the main reason for the species's decline in certain areas (Miller and Pierce 1995). Dog predation may also be an important cause of Kagu decline throughout its range.

Control of dogs to protect Kagus needs to be approached in two ways: reducing the occurrence of dogs straying, and controlling stray dogs in and around Kagu areas. Addressing the latter will necessarily involve the establishment of intensively managed reserves where dogs, and other predators, are controlled. Only one exists, Rivière Bleue Park in the Southern Province. Continuing dog control there by poisoning and shooting has substantially reduced dog presence (Y. Létocart verbally 1994), and these methods can be applied elsewhere. Demarcation of Kagu reserves is necessary but special regulations could apply in them to take account of, for example, traditional hunting. Hunting of Notou Ducula giganta (native pigeon) does not require dogs, and ways of hunting pigs and deer without endangering Kagus should be investigated, for example, use of humane snaring methods or well-trained muzzled dogs.

Reducing the occurrence of straying dogs will not be easy. Dog registration is currently only required in three towns (Nouméa, Poya and Pouembout), where this law is little or not enforced, and stray dogs are commonly seen walking along road margins. In tribal villages, dogs are numerous and have become an integral part of tribal life, for example for hunting, since their introduction in 1774 (Pisier 1974). Because the villages are generally closer to forest and Kagu areas than municipal towns, it will be especially important to involve these communities in Kagu conservation. The stray dog problem can only be solved over the longer term and requires continuing education campaigns about the dog threat to Kagus to encourage greater responsibility in dog ownership and enforcement of dog control laws.

At present only a small number of Kagus are protected (63 pairs censused in Rivière Bleue Park in 1991) and this is not adequate to provide a reasonable chance of long-term Kagu persistence in the wild. The dog attacks at Pic Ningua demonstrate this clearly. Additional reserves are essential in the short term, preferably in a variety of vegetation types, to protect significant numbers of breeding pairs and better insure against catastrophes (Mangel and Tier 1994). For example, the establishment of a managed reserve at Pic Ningua to ensure Kagus remain there should be seriously considered, especially as it would also help protect the important population of tool-using crows Corvus moneduloides living in the forest on the peak (Hunt 1996b).

In summary, dogs are dangerous predators of adult Kagus and efforts to protect birds from dogs will require: (1) the establishment of additional intensively managed reserves in the short term; (2) continuing awareness programmes to educate the public and administrators about the need for Kagu protection and associated dog control; (3) the involvement of tribal communities in Kagu conservation; and (4) the enforcement of dog control laws. 
Establishment of new reserves will also help protect the high endemism and biodiversity (e.g. Chazeau 1993, Jaffré et al. 1994) in New Caledonia's forests.

\section{Acknowledgements}

The Service de l'Environnement et de la Gestion des Parcs et Réserves de la Province Sud allowed us to work in the Pic Ningua Botanical Reserve. SLN (Société le Nickel) mining company gave us permission to use their road to Pic Ningua, and provided accommodation for G.R.H. nearby. We thank Jean-Louis d'Auzon, Marcel Boulet, Michael Bull, Alison Duncan, Etienne Dutailly, Alain van Heck, Yves Létocart, Jacque Locque, Mireille Pandolfi, Serge Sirgouant, and SLN staff at Thio for appreciated support during the dog attacks, Philippe Serre for help with Kagu capture, and Joseph Guillo for finding bird 22. Comments by Murray Potter, Jean-Marc Thiollay, and two anonymous referees, considerably improved the manuscript. This work was carried out under the 'Kagu Project Phase II' funded by BirdLife International and the Royal Society for the Protection of Birds, and managed locally by the Association pour la Sauvegarde de la Nature Néo-Calédonienne.

\section{References}

Brégulla, H. L. (1987) Zur biologie des Kagu, Rhinochetus jubatus. Zool. Gart 57: 349-365.

Chazeau, J. (1993) Research on New Caledonian terrestrial fauna: achievements and prospects. Biodivers. Lett. 1: 123-129.

Collar, N. J., Crosby, M. J. and Stattersfield, A. J. (1994) Birds to Watch 2. The world list of threatened birds. Cambridge, U.K.: Birdlife International (BirdLife Conserv. Series 4).

Jaffré, T., Morat, P. and Veillon, J.-M. (1994) La Flore: caractéristiques et composition floristique des principales formations végétales. Bois et Forêts des Tropiques 242: 7-30.

Jeggo, D. (1978) A preliminary survey report on the Kagu Rhynochetos jubatus of New Caledonia. Dodo 15: 20-28.

Hunt, G. R. (1996a) Environmental variables associated with population patterns of the Kagu Rhynochetos jubatus of New Caledonia. Ibis 138: 778-785.

Hunt, G. R. (1996b) Manufacture and use of hook-tools by New Caledonian crows. Nature 379: 249-251.

Létocart, Y. (1991) Mise en évidence par biotélémétrie de l'habitat utilisé, du comportement territorial et social, et de la reproduction chez le cagou huppé (Rhynochetos jubatus) dans le Parc de la Rivière Bleue. Service de l'Environnement et de la Gestion des Parcs et Réserves de la Province Sud, Nouméa. Unpublished.

Létocart, Y. (1992) Sauvegarde du cagou huppé (Rhynochetos jubatus) dans le Parc Provincial de la Rivière Bleue. Service de l'Environnement et de la Gestion des Parcs et Réserves de la Province Sud, Nouméa. Unpublished.

Mangel, M. and Tier, C. (1994) Four facts every conservation biologist should know about persistence. Ecology 75: 607-614.

McLennen, J. A., Rudge, M. R. and Potter, M. A. (1987) Range size and denning behaviour of Brown Kiwi, Apteryx australis mantelli, in Hawke's Bay, New Zealand. N.Z. J. Ecol. 10: 97-107.

Miller, P. J. and Pierce, R. J. (1995) Distribution and decline of the North Island Brown Kiwi (Apteryx australis mantelli) in Northland. Notornis 42: 203-211.

Pisier, G. (1974) La découverte de la Nouvelle Calédonie par Cook. Nouméa: Société d'Etudes Historique (Publ. 5). 
Sarasin, F. (1913) Die Vögel Neu-Kaledoniens und der Loyalty-Inseln. Pp. 55-60 in F. Sarasin and R. Roux, eds. Nova Caledonia, Zoologie, vol. 1. Wiesbaden: C. W. Kriedels Verlag.

Seitre, R. and Seitre, J. (1990) Rapport de mission 'Cagou' du 25/4/90 au 6/5/90. CNRS/ SRETIE, Paris. Unpublished.

Taborsky, M. (1988) Kiwis and dog predation: observations in Waitangi State Forest. Notornis 35: 197-202.

Thiollay, J.-M. (1989) Etude et conservation du cagou (Rhynochetos jubatus). CNRS/ STRETIE, Paris. Unpublished.

GAVIN R. HUNT and CLARE J. VELTMAN

Department of Ecology, Massey University, Private Bag 11222, Palmerston North, New Zealand

ROD HAY

Department of Conservation, P.O. Box 10420, Wellington, New Zealand. 